\title{
EVALUATION OF THE FACTORS CHARACTERISING HIGH-PERFORMING MAINTENANCE TEAMS IN THE PETROCHEMICAL INDUSTRY
}

\author{
K.C. de Vries ${ }^{1}$ \& J.K. Visser ${ }^{1 *}$
}

\section{ARTICLE INFO}

\section{Article details}

Presented at the $32^{\text {nd }}$ annual conference of the Southern African Institute for Industrial Engineering (SAIIE), held from 4-6 October 2021 in Muldersdrift, South Africa.

Available online

29 Nov 2021

Contact details

Corresponding author

Krige.Visser@up.ac.za

Author affiliations

1 Department of Engineering and

Technology Management,

University of Pretoria, South Africa

\section{ORCID® identifiers}

K.C. de Vries

https: / /orcid.org/0000-0002-3397-0834

J.K. Visser

https://orcid.org/0000-0003-4334-9838

\section{DOI}

http://dx.doi.org/10.7166/32-3-2626

\section{ABSTRACT}

Historically, the maintenance function of an organisation was viewed as a 'necessary evil'; however, the view has shifted to seeing it as a strategic element within an organisation to accomplish its business objectives. For organisations to continue to be competitive, they need to harness the true potential of their people by evaluating ways for maintenance teams to achieve effective teamwork. In the light of this, the study was tailored to determine the factors that characterise high-performing maintenance teams in the petrochemical industry in South Africa. The study determined an importance ranking of these critical factors when implementing highperformance maintenance teams. A questionnaire was used to gather quantitative data from 69 respondents. Analysis of the data revealed that the most important factors for maintenance teams to achieve high performance were knowledge and motivation. It was also found that the most important performance indicators for maintenance were equipment availability, overall equipment effectiveness, and spares availability.

\section{OPSOMMING}

In die verlede is instandhouding in organisasies as 'n onnodige "euwel" beskou. Hierdie siening het egter verander en instandhouding word nou as 'n belangrike strategiese element beskou om die besigheidsdoelwitte van 'n organisasie te behaal. Indien organisasies kompeterend wil bly moet die ware potensiaal van die personeel benut word deur middel van instandhoudingspanne wat effektief saamwerk. In die lig hiervan is 'n studie gedoen om die faktore te bepaal wat kenmerkend is van hoë werkverrigting van instandhoudingspanne in die petrochemiese nywerheid in Suid-Afrika. Die studie het ook ' $n$ rangorde van belangrikheid bepaal van die kritiese faktore vir implementering van hoë-waarde instandhoudingspanne. 'n Vraelys is gebruik om kwantitatiewe data by 69 respondente te verkry. Analise van die resultate het aangedui dat die belangrikste faktore om hoë werkverrigting te verkry vir instandhoudingspanne is "kennis" en "motivering". Daar is ook vasgestel dat die belangrikste prestasiemetings vir instandhouding "toerusting beskikbaarheid", "algehele toerusting effektiwiteit" en "onderdele beskikbaarheid" is.

\section{INTRODUCTION}

\subsection{Background}

In the face of the organisational challenges brought by the growth of the digital revolution and the introduction of new and disruptive technologies, organisations are required to adapt and transform in order to function in a world where dynamism, competitiveness, and the 'war for talent' is the norm. Historically, maintenance was viewed as a 'necessary evil' and as a production task; however, the view has shifted to seeing it as a strategic element within an organisation to accomplish its business objectives and contribute to the bottom line [1]. The industry is faced with a serious challenge: the last of the baby boom generation workforce are on their way out, and with their departure "goes the knowledge which has not been effectively retained for the next generation" [2]. With deteriorating apprenticeship programmes, a decline in educational standards, and the lack of interest in successors in trade professions in the maintenance field, maintenance managers are now faced with the challenge of having to deal with maintenance teams 
that are smaller and that lack the skill and knowledge levels of past generations to execute the same maintenance activity.

With the introduction of lean manufacturing principles in industry, a popular approach used in organisations to improve maintenance performance is total productive maintenance (TPM), which highlights the importance of teamwork to eliminate losses within a maintenance organisation [3]. Adopting a team-based approach to improve team performance has proved effective in many organisations, as mentioned by [4] and [5]. In support of this, [6] explain how organisations are using work teams to recreate themselves and improve team performance, while [2] state that organisations that strive for excellence are generally teambased.

[7] defines a high-performing team (HPT) as a group of individuals who consistently perform and meet the customer's and organisation's needs; their teams regularly “outperform other teams", performing the same function "under similar conditions and constraints", and are "purposeful, social, human-orientated, technical and systematic in nature". However, [5] take a different stance, elaborating on the "critical factors which affect successful implementation of high-performance teams", which are, "organizational impact, defined focus, alignment and interaction with external entities, knowledge and skills, individual needs, measures of performance".

Several studies $[8,9,10,11]$ on high-performing teams have identified characteristic factors; however, little research on the specific attributes of maintenance teams and the application of these conceptual models in a maintenance context has been done.

For organisations to continue to be competitive and survive in an ever-changing world, they need to harness the true potential of their people by evaluating ways to achieve effective teamwork in their maintenance function. In this research, the contribution of teamwork to the successful practice of maintenance was investigated by evaluating the factors that characterise high-performing maintenance teams.

\subsection{Objectives}

The primary objective of this research was to determine the factors or attributes that characterise highperforming maintenance teams in the petrochemical industry. The following secondary objectives were also defined:

- What are the barriers affecting the performance of maintenance teams?

- What are the key performance indicators used to measure the performance of maintenance teams?

\section{LITERATURE}

\subsection{Maintenance performance}

According to [12] and [2], maintenance is defined as a "combination of all technical and administrative actions, including supervision, intended to retain an item, or restore it to a state in which it can perform a required function". Similarly, [13] describe maintenance as a sequence of "coordinated activities that are performed in order to retain an asset in its best operational condition with minimal cost incurred".

The importance of the maintenance function to an organisation is paramount in accomplishing its strategic goals and staying competitive; thus it is necessary for the maintenance functional objectives to be aligned with the organisation's strategic objectives [14, 15, 16]. However, [12] mention that it is common in industry for these functional objectives and performance measures to be inconsistent with the organisation's strategic objectives. [14] describe these performance measures as "too narrowly or too broadly defined". In some cases, the balanced scorecard (BSC) has been used to overcome this by assisting with the development of key performance indicators (KPIs) that align with the organisation's strategic objectives to measure maintenance performance [12]. The challenge in developing these KPIs is to define the success factors for maintenance performance and the focus of the maintenance team [17].

[15] developed a model that portrays the key success factors of the maintenance function that will maximise profit for an organisation. Similarly, [18] and [12] elaborate on the performance measures that are associated with maintenance success. [13] explain why it is important for the performance measurement system to be dynamic in order to handle any changes in the organisation's objectives, regulatory changes, stakeholders' requirements, and technological changes. 
Research studies have been conducted on the most common maintenance performance measures used in organisations, and several models and frameworks have been developed to implement maintenance performance measurement in industry $[19,16,20,14,21]$. These maintenance KPIs can be divided into two categories: leading indicators and lagging indicators. Leading indicators are those that measure performance before the organisational benefit, while lagging indicators measure performance after the organisational benefit [19].

For an organisation to realise the benefits of the maintenance function, the maintenance manager needs to ensure that the KPIs and the maintenance functional objectives are in line with the organisational strategy and objectives. Furthermore, an effective performance measurement system that is relevant to and suitable for the organisation's needs should be used.

\subsection{Factors that influence team performance}

The challenge facing maintenance managers in industry is how to achieve team effectiveness. [22] states that this is "not a new challenge". The discussion of effective teams and work teams leads to a discussion of high-performing maintenance teams.

Effective teamwork can be considered one of the main drivers in high-performing teams. High-performing organisations that sustain their performance are known to have an organisational culture in which teamwork is at the centre [9].

In the model developed by [23], it can be seen how team effectiveness is dynamically interconnected with the perspectives of organisational context, boundaries, and team development. These aspects are further subdivided into several factors that influence team effectiveness.

The organisational context consists of organisational factors such as organisational culture, task design/technology, mission clarity, autonomy, performance feedback, rewards and recognition, and training. The boundaries perspective consists of factors such as work team differentiation and external integration. Team development consists of interpersonal processes, norms, cohesion, and team roles, while team effectiveness comprises performance and viability [23). The aim of this framework is to ensure that the relationships between all of the above-mentioned perspectives and associated factors are interconnected to attain team effectiveness.

Similarly, [24] present a framework that displays the elements of effective integral teamwork and that consists of the following team characteristics: customer and social contribution, sustainability, and organisational, which are subdivided into "right vision and goals, right leadership and team roles, effective procedures and systems, positive relationships and culture, and development and learning".

\subsection{Barriers to achieving maintenance performance}

[25] identified some barriers to the implementation of effective maintenance practices in industry. These are grouped into the following categories: "lack of benchmarking, lack of communication and information, lack of measurement of OEE, lack of teamwork, lack of effective performance measures, lack of commitment of employees towards maintenance, lack of training, lack of proper strategic planning and implementation, lack of top management support, lack of empowerment, and lack of safety and health awareness".

Similarly, [26] grouped the barriers to maintenance implementation into the following categories: resistance to change, poor educational background, open communication, non-availability of standard operating procedures (SOPs), inappropriate tooling, and inappropriate tracking of maintenance data. [27] built on this, categorising the barriers to maintenance performance into the following: "behavioural barriers, human and cultural barriers, strategic barriers, operational barriers and technical barriers". [27] stated that human and cultural barriers are inclusive of "lack of motivation, recognition and empowerment", and technical barriers can be treated by training and developing employees on the principles of quality management systems.

\subsection{Characteristics of high-performing maintenance teams}

[10] defined a high-performing organisation (HPO) as an organisation that outperforms its competitors over prolonged periods of time "by adapting well to changes and reacting quickly", through prioritising their employee's needs, "setting up an integrated and aligned management structure", by strategically improving the "core capabilities", and thinking for the future. 
[7] defined a high-performing team (HPT) as a group of individuals who consistently perform and meet the customer's and organisation's needs, where these teams regularly "outperform other teams" performing the same function and "under similar conditions and constraints". He explained that high-performing teams are "purposeful, social, human-orientated, technical and systematic in nature".

[8] described high-performing teams as those that have the following characteristics:

- $\quad$ Leadership that leads by example

- $\quad$ Results-driven and quality-driven

- Possess a "high degree of job satisfaction from their work"

- Co-operation among each other

- $\quad$ Balanced group of individuals who are self-managed

- Continuously learning from mistakes

- Teams that are "customer orientated"

- Problem-solvers

- Motivated individuals

[9] described the important characteristics of high-performing teams as those in which the individuals:

- Have mutual respect and "trust in each other"

- Are supportive of every individual in the team

- Openly engage in communication

- Have the same objective

- Share the same "values and beliefs"

- Have objectives that are are subservient to those of the team

- $\quad$ Are managed and led by effective leadership

[5] identified a number of critical factors for the successful implementation of high-performance teams from the literature, and tested the model at an engineering company in the UK. The model comprised the critical factors "organisational impact, defined focus, alignment and interaction with external entities, knowledge and skills, individual needs, measures of performance and group culture".

The reviewed literature on maintenance performance and the KPIs to measure success was best portrayed in the research study by [19]. While several literature sources have written on the characteristics of effective teamwork and high-performing teams, these frameworks and factors lack acknowledgement and contextualisation within the maintenance field. In this research, the factors that are characteristic of highperforming maintenance teams and effective work teams were validated in respect of maintenance team performance.

\section{RESEARCH METHODOLOGY}

The factors that influence maintenance team performance were evaluated by gathering data in the petrochemical industry, using quantitative methods. [28] note that "quantitative methods are an important part of the research process". Quantitative research methods use statistical and graphical methods to analyse numerical data to examine the relationships between variables [29]. For the current research it was proposed that the maintenance function, and therefore performance of the maintenance team, is influenced by 39 critical success factors, classified under the following six general categories.
1) Organisational factors
2) Leadership factors
3) Motivational factors
4) Knowledge and skill factors
5) Performance factors
6) Communication factors

The 39 critical factors were extracted from a number of literature sources - mostly [23], [24], and [25]. Some were also derived from the barriers to achieving performance in maintenance as discussed in section 2.3. [30] provides a detailed list of these factors, grouped under the six categories used for this research study. 
The sample population selected for the current study were stakeholders of the maintenance function, which includes the maintenance foremen, maintenance area managers, reliability engineers, maintenance technicians, and senior maintenance managers from two operating entities within the chosen organisation in the petrochemical industry in South Africa.

A survey questionnaire was compiled and sent to 250 maintenance personnel from two business units within the selected organisation. The survey questions were categorised into the following: (1) general information, (2) organisational context, (3) motivation (4), leadership, (5) communication, (6) performance measurement, (7) Knowledge, and (8) maintenance performance indicators. In the introductory section of the questionnaire, several questions were asked of the participants to obtain specific information about their roles in the maintenance function, and their level of experience. This information was deemed important as it portrayed the ability of the participants to respond to the survey questions asked. The next six sections focused on the different categories of factors, where a specific characteristic was tested.

Maintenance management involves performance measurement. However, each organisation defines its own KPIs for maintenance, and there is no universally accepted set of KPIs to perform comparisons and to give to the maintenance teams as objectives. The importance of KPIs for maintenance was therefore also evaluated using a questionnaire. [19] did an extensive review of KPIs for maintenance, in which the respondents were asked to indicate the importance of the KPIs defined by [19], shown in Table 1 below, on a five-point scale.

Table 1: Performance indicators (adopted from [19])

\begin{tabular}{|c|c|c|c|}
\hline \multicolumn{2}{|c|}{ Category } & Type & Performance indicator \\
\hline $\mathrm{P}-1$ & Work identification & Leading & $\%$ available man hours used in proactive work \\
\hline P-2 & Work identification & Leading & Number of work order requests \\
\hline P-3 & Work planning and scheduling & Leading & $\begin{array}{l}\% \text { scheduled man hours over total available man } \\
\text { hours }\end{array}$ \\
\hline P-4 & Work execution & Leading & $\%$ work orders (WO) with due date compliance \\
\hline P-5 & Work execution & Leading & $\%$ work orders (WO) in backlog \\
\hline P-6 & Work execution & Leading & Mean time to repair (MTTR) \\
\hline P-7 & Work execution & Leading & Number of quality non-conformances \\
\hline P-8 & Work execution & Leading & Spare parts availability \\
\hline P-9 & Equipment effectiveness & Lagging & Number of unplanned maintenance interventions \\
\hline P-10 & Equipment effectiveness & Lagging & Breakdown frequency \\
\hline P-11 & Equipment effectiveness & Lagging & Breakdown ratio \\
\hline P-12 & Equipment effectiveness & Lagging & Mean time between failures (MTBF) \\
\hline P-13 & Equipment effectiveness & Leading & Unscheduled maintenance downtime \\
\hline P-14 & Equipment effectiveness & Lagging & Equipment availability \\
\hline P-15 & Equipment effectiveness & Lagging & Overall equipment effectiveness (OEE) \\
\hline P-16 & Equipment effectiveness & Lagging & $\begin{array}{l}\text { Maintenance mix (proactive work orders/total work } \\
\text { orders) }\end{array}$ \\
\hline P-17 & Equipment effectiveness & Lagging & Mean time between incidents (MTBI) \\
\hline P-18 & $\begin{array}{l}\text { Maintenance cost } \\
\text { effectiveness }\end{array}$ & Lagging & Maintenance cost per product unit \\
\hline P-19 & $\begin{array}{l}\text { Maintenance cost } \\
\text { effectiveness }\end{array}$ & Lagging & $\%$ maintenance cost over replacement value \\
\hline P-20 & $\begin{array}{l}\text { Maintenance cost } \\
\text { effectiveness }\end{array}$ & Lagging & $\%$ maintenance cost over sales revenue \\
\hline P-21 & Safety and environment & Lagging & $\begin{array}{l}\text { Number of safety, health, and environment (SHE) } \\
\text { incidents }\end{array}$ \\
\hline P-22 & Maintenance human factors & Leading & Skill and competence \\
\hline P-23 & Organisational factors & N/A & Growth in market share \\
\hline
\end{tabular}

The survey questionnaire comprised 43 questions and statements from the categories mentioned above. An invitation to take part in the study was sent out via email. Some 75 responses were received from the survey; however, owing to some responses being incomplete, only 69 responses were retained for the analysis. Since the invitation was sent out via email, and participation was anonymous, conclusions could not be drawn on the reasons for the non-participation of some in the selected sample.

All of the information gathered from the survey questionnaire was exported from Qualtrics to an Excel worksheet and file, and then imported into the SPSS statistical software for further analysis and interpretation. The raw data file was modified to remove the incomplete responses received. The mean values and standard deviations were determined from the responses obtained for each measured variable. 
The results obtained from the survey questionnaire reflected the perceptions of the supervisors, maintenance managers, and maintenance support functions in the selected operating entities of the petrochemical organisation. The selection of the sample population was based on the active role that these maintenance personnel play in the maintenance function.

Some 34 per cent of the respondents were first-line management (e.g., foreman level), 35 per cent were maintenance management (e.g., area manager), 16 per cent were maintenance technicians, seven per cent were senior maintenance management, and eight per cent were from maintenance support functions. All levels of management and support roles were well-represented, and most of the respondents were individuals who are directly involved with the day-to-day execution and management of maintenance activities.

The levels of experience of the responses received were as follows: 86 per cent of the respondents had more than five years of experience in the maintenance environment, and thus were deemed knowledgeable about maintenance best practices, while 71 per cent of the respondents had more than 10 years' experience.

In order to achieve variation and to be able to generalise the results for the entire petrochemical industry, two operating entities were selected for the study, from which the distribution of the responses received was a 65 to 35 per cent split between them.

\subsection{Organisational factors}

There was general agreement among the respondents that organisational factors influence the performance of maintenance teams. Factors such as shared values and beliefs, shared accountability, clearly defined roles and responsibilities, clearly defined purpose and focus, external orientation, cohesiveness, trust and openness, and organisational structure were regarded as most characteristic of high-performing maintenance teams. It was noticeable that the respondents were undecided on factors such as informal work environment and task variability and complexity, which were deemed not to be necessarily characteristic of high-performing maintenance teams. Figure 1 ranks the top 10 organisational factors in order of the ratio of respondents who strongly agreed that the organisational factor is characteristic of high-performing maintenance teams.

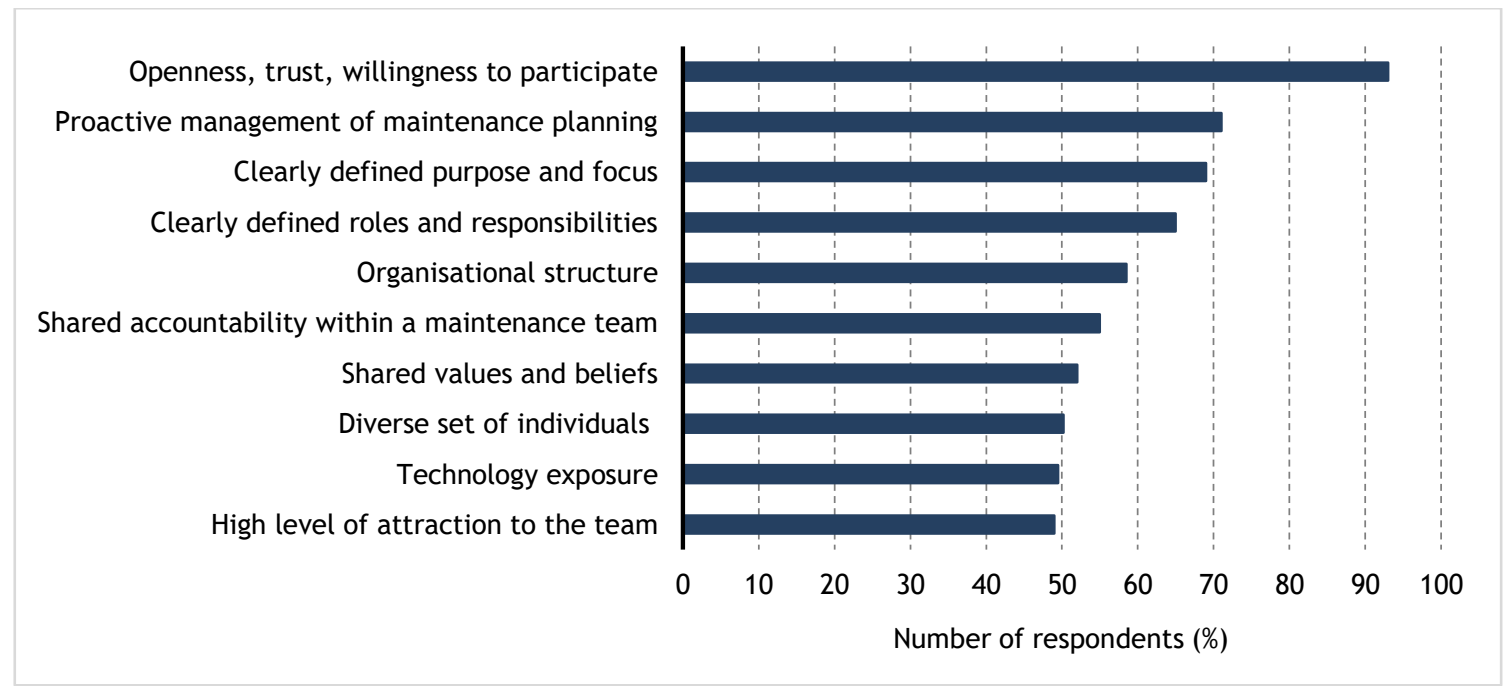

Figure 1: Importance of organisational factors

\subsection{Motivational factors}

The influence that motivational factors have on maintenance team performance was measured using five questions in the survey. The results that were obtained revealed a general agreement among the respondents that the factors that motivate individuals have a direct influence on the performance of maintenance teams. Factors such as feeling appreciated, high job satisfaction, a team-based environment, 
and performance-based recognition were regarded as most characteristic of high-performing maintenance teams. Figure 2 ranks the motivational factors in order of the ratios of the respondents who strongly agreed that the motivational factor is characteristic of high-performing maintenance teams.

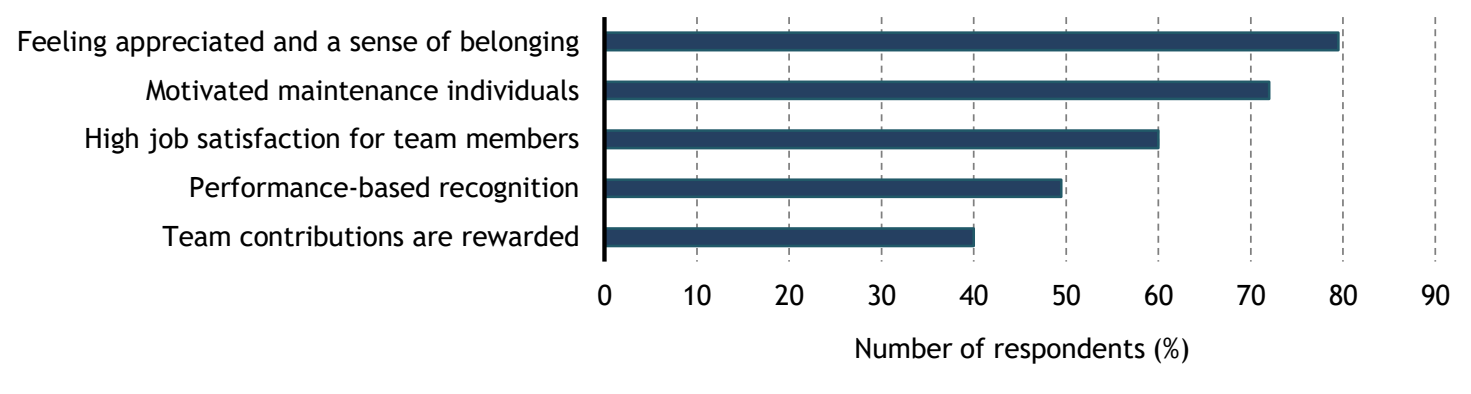

Figure 2: Importance of motivational factors

\subsection{Leadership factors}

It is said that effective leadership is important for high-performing teams; and so several leadership factors were tested in the survey questionnaire. The results that were obtained showed a general agreement among the respondents about the effect of leadership on maintenance team performance. Factors such as leadership that leads by example, shared leadership, empowered teams, and participative leadership were regarded as most characteristic of high-performing maintenance teams. There was some uncertainty about informed risk-taking being a characteristic of high-performing maintenance teams. Figure 3 ranks the leadership factors in order of the ratios of the respondents who strongly agreed that the leadership factor is characteristic of high-performing maintenance teams.

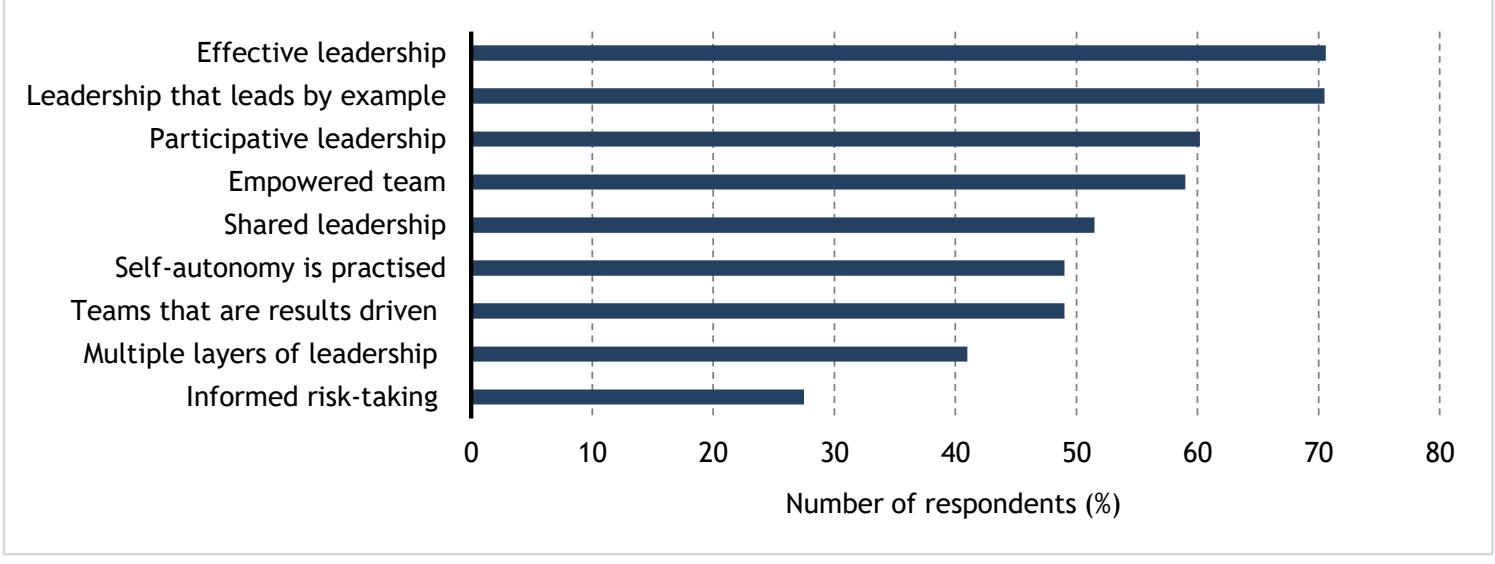

Figure 3: Importance of leadership factors

\subsection{Communication factors}

Several communication factors were evaluated in the survey for their influence on team performance. The results obtained showed a general agreement among the respondents. One factor that did not have full agreement among the respondents was decentralised communication. It can be said that, even though this type of communication is highly effective, at times there is a need for structured/centralised communication. The way the organisation is structured - in this case, a functional structure - does not allow for such communication and shared authority. Figure 4 ranks the communication factors in order of the ratios of the respondents who strongly agreed that the communication factor is characteristic of highperforming maintenance teams. 


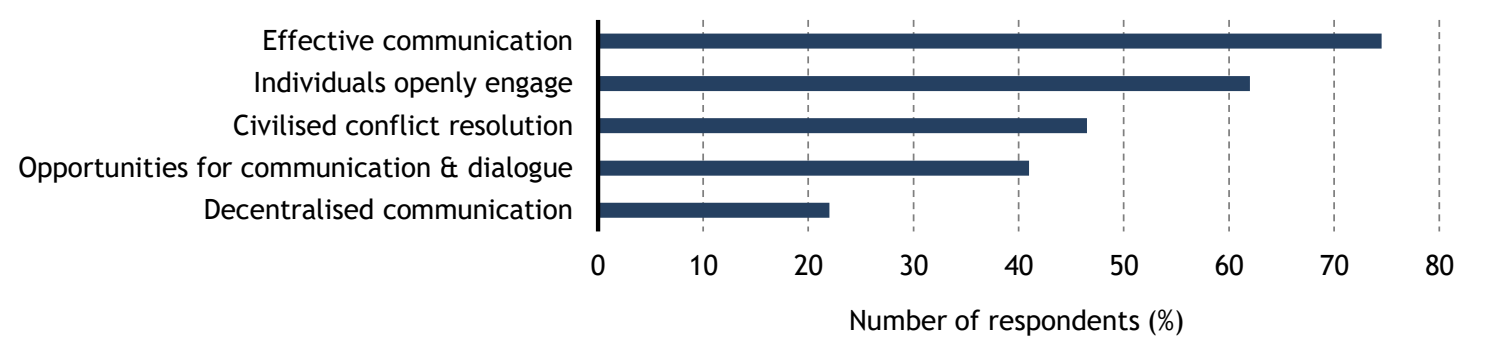

Figure 4: Importance of communication factors

\subsection{Performance factors}

The aim of this section was to determine the performance factors that influence team effectiveness and performance as perceived by the respondents. Several questions were posed to test this and to relate it to high-performing maintenance teams. The responses received showed a general agreement among the respondents that performance factors influence maintenance team performance. Factors such as timely feedback on performance, regular engagement on performance, and an effective performance measurement system were regarded as most characteristic of high-performing maintenance teams. Figure 5 ranks the performance factors in order of the ratios of the respondents who strongly agreed that the performance factor is characteristic of high-performing maintenance teams.

Timely feedback on performance

Regular engagement with leader

Effective performance measurement System that measures team deliverables

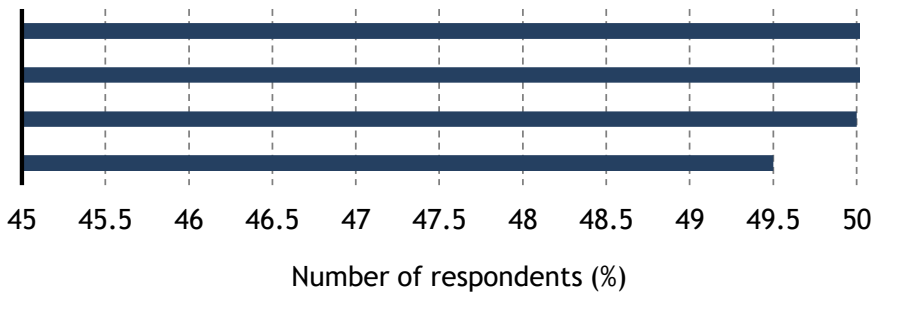

Figure 5: Importance of performance factors

\subsection{Knowledge and skills factors}

The knowledge and skills attributes in a team influence its performance. Thus the effect of several factors was tested to check how they related to high-performing maintenance teams. From the responses received, there was a general agreement among the respondents that knowledge factors influence maintenance team performance and that the following factors are characteristic of high-performing maintenance teams: knowledge-sharing practices, diverse skills and competence levels, personal development, and continuous development. Figure 6 ranks the knowledge factors in order of the ratios of the respondents who strongly agreed that the knowledge factor is characteristic of high-performing maintenance teams.

Knowledge sharing within team

Knowledge is upgraded to acquire proficiency

Team with strong cognitive ability \& skills

Opportunities for personal development

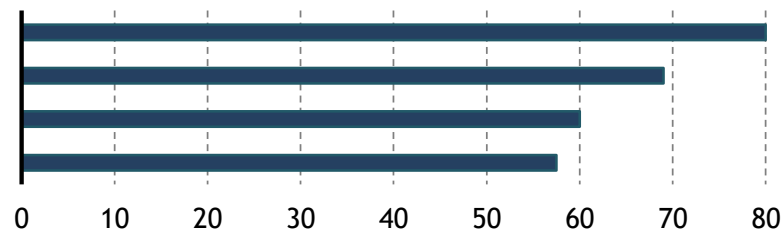

Number of respondents (\%)

Figure 6: Importance of knowledge and skill factors

\subsection{High-performing maintenance teams}

When comparing the mean values of the six different categories, the knowledge factors and the motivational factors were deemed more important than the other factors in relation to their influence on 
maintenance team performance. Table 2 illustrates the importance of these factors for maintenance team performance as specified by the survey respondents.

Table 2: Importance of categories of factors

\begin{tabular}{|l|l|l|}
\hline Categories & Ranking & Ratio (\%) \\
\hline Knowledge factors & 1 & 50,2 \\
\hline Motivational factors & 2 & 49,9 \\
\hline Leadership factors & 3 & 47,7 \\
\hline Organisational factors & 4 & 46,4 \\
\hline Communication factors & 5 & 46,3 \\
\hline Performance factors & 6 & 45,8 \\
\hline
\end{tabular}

\subsection{Maintenance performance indicators}

The respondents were requested to provide their opinion on the level of importance of several maintenance performance indicators. The maintenance performance indicators that were deemed more important in measuring maintenance performance were: equipment availability, overall equipment effectiveness, spare parts availability, skill and competence, MTBF, and proactive maintenance ratio (percentage of available man-hours used in proactive work). Figure 7 indicates the top 10 maintenance performance indicators as ranked by the respondents.

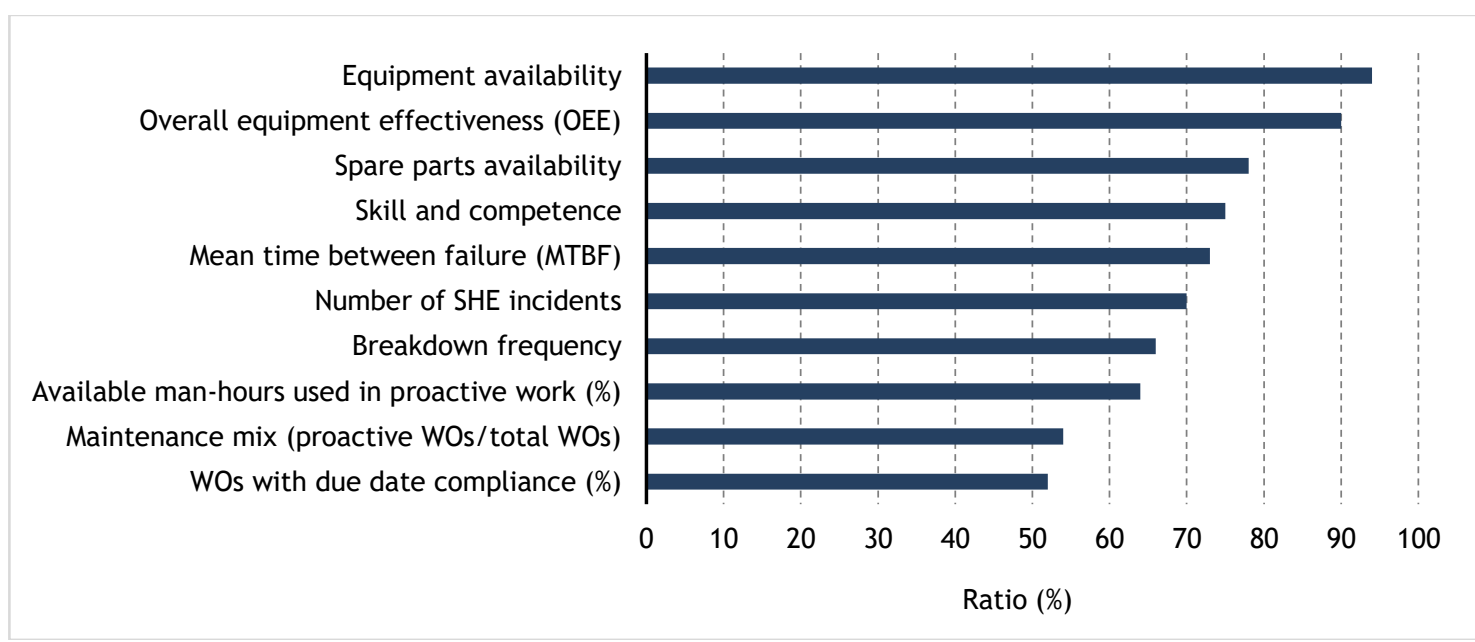

Figure 7: Top 10 maintenance performance indicators

\section{CONCLUSIONS AND RECOMMENDATIONS}

\subsection{Conclusions}

The primary objective of this study was to establish and analyse the factors that characterise highperforming maintenance teams. The literature study confirmed that the topic of team performance and high-performing teams has been discussed extensively in the literature. However, little research has been done on maintenance teams exclusively. This research study contributes to the literature on highperforming maintenance teams in the petrochemical industry in South Africa. The findings of the study could be used by asset and maintenance managers in petrochemical industries to improve the performance of their maintenance teams and therefore also the maintenance division or the department as a whole. However, owing to the limited number of respondents in this research study (i.e., 69 respondents), the findings cannot be generalised to other industries.

\subsubsection{Factors that characterise high performance teams}

The factors that characterise high-performing maintenance teams were extracted from the existing literature and used in this research to develop a model to investigate whether these theories also apply to maintenance teams in the petrochemical industry in a developing and emerging economy such as South Africa. The following factors were selected by the participants as the most important for high-performing maintenance teams: 
- Motivated individuals

- High job satisfaction

- Performance-based recognition

- $\quad$ Rewarding of individual and team contributions

- Individuals who feel appreciated and have a sense of belonging in the team

The factors that were identified and confirmed through this research can be summarised under the following categories: organisational factors, motivational factors, communication factors, leadership factors, knowledge factors, and performance measurement factors.

\subsubsection{Barriers or obstacles that affect the performance of maintenance teams}

Barriers to the implementation of effective maintenance management were identified from the literature. [31] identified the following categories of barriers to high performance teams: technical, economic, managerial, organisational, and cultural/environmental. Similarly, [27] categorised the barriers as behavioral, human and cultural, strategic, operational, and technical.

\subsubsection{Core indicators used to measure performance of maintenance teams}

The maintenance performance indicators that were deemed most important in measuring maintenance performance were equipment availability, overall equipment effectiveness, and spare parts availability. It is important to note that the measures mentioned as more important are those that are internal to the maintenance team, and do not include any external measures (such as growth in market share or customer satisfaction).

\subsection{Recommendations}

This study was limited to the petrochemical industry, and did not include other industries. It is recommended, therefore, that the factors that influence the performance of maintenance teams and that have been identified in the petrochemical industry be tested in other asset-intensive industries such as energy, transport, communications, and mining. A further study should investigate the relationships between the various factors and their influence on maintenance team performance.

\section{REFERENCES}

[1] L. Pintelon, A. Parodi-Herz, K. Kobbacy, \& P. Murthy, Complex system maintenance handbook, Springer Series in Reliability Engineering, Vol. 10. Springer-Verlag, London, 2008.

[2] J.D. Campbell, \& J.V. Reyes-Picknell, Uptime: Strategies for excellence in maintenance management. $3^{\text {rd }}$ edition, CRC Press, Boca Raton, 2016.

[3] C.J. Bamber, J.M. Sharp, \& M.T. Hides, "Factors affecting successful implementation of total productive maintenance", Journal of Quality in Maintenance Engineering, vol. 5, no. 3, pp. 162-181, 1999.

[4] R.G. Rowe, “Towards a team-based approach", Career Development International, vol. 1, no. 2. pp. 19-24, 1996.

[5] C. Castka, C.J. Bamber, J.M. Sharp, \& P. Belohoubek, "Factors affecting successful implementation of high performance teams", Team Performance Management, vol. 7, no. 7/8, pp. 123-34, 2001.

[6] H. Doorewaard, R. Huys, \& G. Van Hootegem, "Team responsibility structure and team performance", Personnel Review, vol. 31, no. 3, pp. 356-70, 2002.

[7] E. Kur, "The faces model of high performing team development", Leadership \& Organization Development Journal, vol. 17 , no. 1 , pp. $32-41,1996$.

[8] C. Margerison, \& D. McCann, "High performing managerial teams", Leadership \& Organization Development Journal, vol. 5, no. 5, pp. 9-13, 1984.

[9] M.F.R.K. de Vries, "Lessons from the Pygmies", Organizational Dynamics, vol. 27, no. 3, pp. 66-77, 1999.

[10] A.A. de Waal, "The characteristics of a high performance organization", Business Strategy Series, vol. 8, no. 3, pp. 179-185, 2007.

[11] L. Mealiea, \& R. Baltazar. "A strategic guide for building effective teams”, Public Personnel Management, vol. 34, no. 2, pp. 141-160, 2005.

[12] A.C. Márquez, P. Moreu de León, J.F. Gómez Fernández, C. Parra, \& M.A. López Campos, "The maintenance management framework", Journal of Quality in Maintenance Engineering, vol. 15, no. 2, pp. 167-178, 2009.

[13] A. Parida, U. Kumar, D. Galar, \& C. Stenström, "Performance measurement and management for maintenance: A literature review", Journal of Quality in Maintenance Engineering, vol. 21, pp. 2-33, 2015.

[14] H.C. Tsang, A.K.S. Jardine, \& H. Kolodny, "Measuring maintenance performance: A holistic approach", International Journal of Operations \& Production Management, vol. 19, no. 7, pp. 691-715, 1999.

[15] C. Cholasuke, J. Antony, \& R. Bhardwa, "The status of maintenance management in UK manufacturing organizations: Results from a pilot survey", Journal of Quality in Maintenance Engineering, vol. 10, no. 1, pp. 5$15,2004$.

[16] A. Parida, \& U. Kumar, "Maintenance performance measurement (MPM): Issues and challenges”, Journal of Quality in Maintenance Engineering, vol. 12, no. 3, pp. 239-51, 2006.

[17] J.D. Campbell, A.K.S. Jardine, \& J. McGlynn, Optimizing equipment life cycle decisions. CRC Press Boca Raton 2006. 
[18] A.C. Marquez, The maintenance management framework. Springer-Verlag, London, , 2007.

[19] U. Kumar, D. Galar, A. Parida, C. Stenström, \& L. Berges, "Maintenance performance metrics: A state-of-the-art review", Journal of Quality in Maintenance Engineering, vol. 19, no. 3, pp. 233-277, 2013.

[20] J.M. Simões, C.F. Gomes, \& M.M. Yasin, “A literature review of maintenance performance measurement", Journal of Quality in Maintenance Engineering, vol. 17, no. 2, pp. 116-137, 2011.

[21] M. Oliveira, I. Lopes, \& C. Rodrigues, "Use of maintenance performance indicators by companies of the industrial hub of Manaus", Procedia CIRP, vol. 52, pp. 157-160, 2016.

[22] S. Kellett, Effective teams at work, Management Development Review, vol. 6, no. 1, pp. 1-6, 1993.

[23] E. Sundstrom, \& D. Futrell, “Work teams applications and effectiveness", American Psychologist, vol. 45, no. 2, pp. 120-133, 1990.

[24] R. Cacioppe, \& R. Stace, “Integral team effectiveness: Validity analysis of a theory-based team measure”, Team Performance Management: An International Journal, vol. 15, no. 5/6, pp. 220-234, 2009.

[25] R.K. Singh, A. Gupta, A. Kumar, \& T.A. Khan, "Ranking of barriers for effective maintenance by using TOPSIS approach", Journal of Quality in Maintenance Engineering, vol. 22, no. 1, pp. 18-34, 2016.

[26] G. Kanesvaran, "Critical success factor and barriers in implementation of total productive maintenance", A dissertation for the Master of Management (Technology) degree, Faculty of Management, Universiti Teknologi Malaysia, 2018.

[27] M.A. Munir, M.A. Zaheer, M. Haider, M.Z. Rafique, M.A. Rasool, M. Saad, \& M. Amjad, "Problems and barriers affecting total productive maintenance implementation”, Technology \& Applied Science Research, vol. 9, no. 5, pp. 4818-4823, 2019.

[28] M. Easterby-Smith, R. Thorpe, \& P. Jackson, Management \& business research, $5^{\text {th }}$ edition, SAGE Publications, 2015.

[29] M. Saunders, P. Lewis, \& A. Thornhill, Research methods for business students, $5^{\text {th }}$ edition, Prentice Hall, 2009.

[30] K.C. de Vries, "Evaluation of the factors characterizing high performance maintenance teams in the petrochemical industry". Master's research project report, Department of Engineering and Technology Management, University of Pretoria, 2020.

[31] O.M. Mohamed, "Identifying the barriers affecting quality in maintenance within Libyan manufacturing organizations", PhD dissertation, School of Management, University of Salford, 2005.

[32] R. Peach, H. Ellis, \& J.K. Visser, "A maintenance performance measurement framework that includes maintenance human factors: A case study from the electricity transmission industry", South African Journal of Industrial Engineering, vol. 27, no. 2, pp. 177-189, 2016. 